Global Sustainability

cambridge.org/sus

\section{Intelligence Briefing}

tDeceased

Cite this article: Roberts JT, Steinberger JK, Dietz T, Lamb WF, York R, Jorgenson AK, Givens JE, Baer P, Schor JB (2020). Four agendas for research and policy on emissions mitigation and well-being. Global Sustainability 3, e3, 1-7. https://doi.org/ $10.1017 /$ sus. 2019.25

Received: 31 May 2019

Revised: 8 November 2019

Accepted: 11 November 2019

\section{Keywords:}

climate change; low-carbon; well-being; decoupling; development pathways

Author for correspondence:

J. Timmons Roberts, E-mail: timmons@brown. edu.

\title{
Four agendas for research and policy on emissions mitigation and well-being
}

\author{
J. Timmons Roberts ${ }^{1}$ (D), Julia K. Steinberger ${ }^{2}$, Thomas Dietz ${ }^{3}$, \\ William F. Lamb ${ }^{4}$ (D), Richard York ${ }^{5}$, Andrew K. Jorgenson ${ }^{6}$, \\ Jennifer E. Givens ${ }^{7}$, Paul Baer† and Juliet B. Schor ${ }^{8}$
}

${ }^{1}$ Institute at Brown for Environment and Society, Brown University, Box 1951, 135 Angell Street, Providence, RI 02912 USA; ${ }^{2}$ Sustainability Research Institute, School of Earth \& Environment, University of Leeds, Leeds LS2 9JT, UK; ${ }^{3}$ Environmental Science and Policy Program and Department of Sociology, 6J Berkey Hall, Michigan State University, East Lansing, MI 48824 USA; ${ }^{4}$ Mercator Research Institute on Global Commons and Climate Change (MCC), Torgauer Str. 12-15, 10829 Berlin, Germany; ${ }^{5}$ Department of Sociology and Environmental Studies Program, 1291 University of Oregon, Eugene, OR 97403 USA; ${ }^{6}$ Department of Sociology and Environmental Studies Program, Boston College, 140 Commonwealth Avenue, Chestnut Hill, MA 02467 USA; ${ }^{7}$ Department of Sociology, Social Work, and Anthropology, Utah State University, 0730 Old Main Hill, Logan, UT 84322 USA and ${ }^{8}$ Department of Sociology, Boston College, 140 Commonwealth Avenue, Chestnut Hill, MA 02467, USA

\section{Non-technical abstract}

The climate crisis requires nations to achieve human well-being with low national levels of carbon emissions. Countries vary from one another dramatically in how effectively they convert resources into well-being, and some nations with low levels of emissions have relatively high objective and subjective well-being. We identify urgent research and policy agendas for four groups of countries with either low or high emissions and well-being indicators. Least studied are those with low well-being and high emissions. Understanding social and political barriers to switching from high-carbon to lower-carbon modes of production and consumption, and ways to overcome them, will be fundamental.

\section{Technical abstract}

In order for rapid decarbonization of the world's economies to be consistent with staying within 1.5 (or even 2 ) ${ }^{\circ} \mathrm{C}$ of warming limits, research is urgently needed on the potential for decoupling human well-being improvements from energy use and greenhouse gas emissions. Improving human well-being is both a higher moral priority, and a more promising candidate for decoupling, than economic growth. Research needs to include the difficult political-economic, judicial and institutional changes needed to support transitions to high wellbeing and low-carbon pathways. Much of this work will be nation-specific, but it is useful to examine pathways for four groups of nations. We propose an initial set of research questions for each group of nations, on their history and current situation, and on pathways to rapid decarbonization. Existing technology now makes it feasible to achieve low carbon emissions and high human well-being for all nations. But the barriers are substantial, and include addressing existing vested interests of economic sectors, technological lock-in, assumptions embedded in culture, and political structures. Unfortunately, these areas are currently the weakest link in the existing research and policy chain.

\section{Social media summary}

New piece lays out research agenda for national development that advances human well-being while deeply cutting emissions.

(C) The Author(s) 2020. This is an Open Access article, distributed under the terms of the Creative Commons AttributionNonCommercial-ShareAlike licence (http:// creativecommons.org/licenses/by-nc-sa/4.0/), which permits non-commercial re-use, distribution, and reproduction in any medium, provided the same Creative Commons licence is included and the original work is properly cited. The written permission of Cambridge University Press must be obtained for commercial re-use.

\section{CAMBRIDGE} UNIVERSITY PRESS

\section{Introduction}

A key challenge of climate change is that past economic expansion has been fuelled by relatively cheap and abundant fossil energy. Some countries, however, have achieved high levels of well-being at relatively low levels of carbon emissions; learning from these countries may enable us to understand key features of feasible and desirable development pathways for different groups of countries.

These countries show that it is possible to achieve human well-being (as measured by both objective indicators such as high life expectancy and literacy rates and subjective measures such as life satisfaction) with rather moderate national levels of carbon emissions or other stressors on the environment (Dietz et al., 2009, 2012; Jorgenson, 2014; Knight \& Rosa, 2011; Mazur \& Rosa, 1974; Steinberger et al., 2012). Nations vary dramatically from one 
another in how effective they are at converting resources into wellbeing, and a diverse group of nations with moderate levels of resource consumption have relatively high objective and subjective well-being, whether measured by direct or trade-adjusted emissions at the national level (Dietz et al., 2009, 2012; Givens, 2017, 2018; Jorgenson, 2014; Jorgenson et al., 2018; Knight \& Rosa, 2011; Lamb et al., 2014; Mazur \& Rosa, 1974; O’Neill et al., 2018; Steinberger \& Roberts, 2010; Steinberger et al., 2012). Though there are important caveats in transferring lessons across nations and variations in efficiency of delivering well-being even within nations (Geronimus et al., 2001; Otto et al., 2019), these findings suggest that there are routes to improving wellbeing that do not rely on expanding emissions beyond a modest threshold, and hence could be consistent with the rapid decarbonization required for avoiding dangerous warming levels (Grubler et al., 2018; IPCC, 2018). The urgency of this work is clear from recent studies confirming that even moderate emissions create stresses that are already sufficient to breach planetary boundaries (IPCC, 2018; O’Neill et al., 2018),

In 2015 nearly all of the world's nations developed and submitted pledged actions on climate change ('Intended Nationally-Determined Contributions' - INDCs) for the Paris round of negotiations of the UNFCCC (UNFCCC, 2015), and these are due to be updated in 2020. Analyses suggest these pledges will fail to meet the $2^{\circ} \mathrm{C}$ and $1.5^{\circ} \mathrm{C}$ limits set out in the agreement (Rogelj et al., 2016; UNEP, 2018). Nor do the INDCs refer substantively to human well-being in their content (Atteridge et al., 2019). The task going forward is to convert these pledges into national development plans that rapidly phase out greenhouse gas emissions and build climate resilience, while maintaining or improving human well-being in equitable ways (Lamb \& Steinberger, 2017; McCollum et al., 2018; Rao \& Min, 2017). This suggests to us four logical and urgent research and policy agendas on climate and development that we lay out here, for countries with (1) high emissions, (2) lower well-being, (3) both high emissions and low well-being, (4) and also countries with higher well-being and lower emissions. Little research has proposed decarbonization pathways for the smaller set of nations who have achieved neither economic prosperity nor high wellbeing, in spite of relatively high emissions; these nations should be a natural focus for research and international private and public cooperation.

\section{Carbon emissions and human well-being}

The relatively cheap and abundant energy that fuelled past economic expansions created a common belief that expanding energy consumption and carbon emissions was necessary to improve people's lives (Stiglitz et al., 2010, 2017). This belief is actively reinforced by millions of dollars spent in public relations campaigns funded by the fossil fuel industry (e.g. Brulle, 2019; Sheehan, 2018). In reality, however, the relationships among human well-being, economic activity and energy and carbon emissions are complex, varied and dynamic (Smil, 2008). At least since the 1970s it has been clear that there is no lockstep relationship between energy consumption and well-being (Mazur \& Rosa, 1974).

A new understanding of these relationships, one that acknowledges that human well-being is not identical with economic purchasing power, is essential to addressing the climate crisis (Gough, 2015; Stiglitz et al., 2017). Many metrics for well-being, based on both objective and subjective measures, have been proposed and examined (Lamb \& Steinberger, 2017). What is common among them is that they draw a distinction between well-being on the one hand, and affluence measured via consumption and economic production, on the other. Here we use the widely available indicator of life expectancy at birth to represent the overarching outcome of multiple well-being dimensions, including health care provision, sanitation, gender equality, poverty alleviation, social inclusiveness and education. While a single indicator can never represent the full range of human well-being, life expectancy encapsulates the ability of a society to provide multiple dimensions of well-being for its population (see Steinberger \& Roberts, 2010). Life expectancy measures also tend to be relatively valid and reliable for comparisons between nations and through time. Other indicators, including well-developed measures of subjective well-being (OECD, 2013), categorize countries in nearly the same way (Fanning \& O’Neill, 2019; Knight \& Rosa, 2011).

The complexity of the relationship between human well-being and emissions can be seen through the vast diversity in national locations on a plot of per capita emissions and average life expectancy at birth (Figure 1). A number of factors interact to create this variation, ${ }^{\mathrm{i}}$ which is substantial. The overall picture in 2016 was that the countries with the highest life expectancies, above 75 years, had trade-adjusted emissions ranging from under one ton of carbon dioxide per capita to as much as 27 tons (Albania \& UAE respectively). Countries with very modest levels of emissions, below 1.5 tons of carbon dioxide per capita, achieved average life expectancies ranging between 53 and 77 years (Swaziland and Albania). This suggests there is no simple relationship between these two variables. A diverse group of countries is situated within what we have termed 'Goldemberg's Corner' (Steinberger \& Roberts, 2010) of high life expectancy (above 70 years) with moderate carbon dioxide emissions (below 3.5 tons $\mathrm{CO}_{2}$ per capita). ${ }^{\mathrm{ii}}$ This desirable location includes countries in South America, North Africa, Asia and the Reforming Economies in Eastern Europe, with diverse climates, economic structures, histories and political regimes (Lamb et al., 2014; Steinberger \& Roberts, 2010).

While historical patterns do not foreclose future options opened by the plunging price of renewables such as wind, solar, geothermal, wave and tidal energy, understanding the approaches and performance of countries that have achieved high human well-being outcomes with low carbon emissions in the past may help reveal important development pathways compatible with a stable climate system. Studies have found the geographic diversity of such countries to be matched by their diversity in economies and carbon emissions (Lamb et al., 2014). For instance, Costa Rica, Peru and Brazil have warmer climates, a lower propensity to engage in international trade, and higher rates of population growth, compared to a quite different group of countries in Goldemberg's Corner: Albania, Armenia and Georgia (Lamb et al., 2014). Warm, international trade-intensive nations such as Thailand and Vietnam are also present in this desirable space of high well-being with moderate emissions.

Even more impressive than the current situation are the dynamics implied by the change in the relationship between emissions and life expectancy over time (Givens, 2017, 2018; Jorgenson, 2014). Far from remaining static, the emissions levels in relation to high life expectancy outcomes have been decreasing steadily, and rapidly. In 1975, a life expectancy of 70 years was associated with, on average, over 7 tons of carbon dioxide emissions per capita, and was only within the reach of the most industrialized countries. Thirty years later, the average level of 


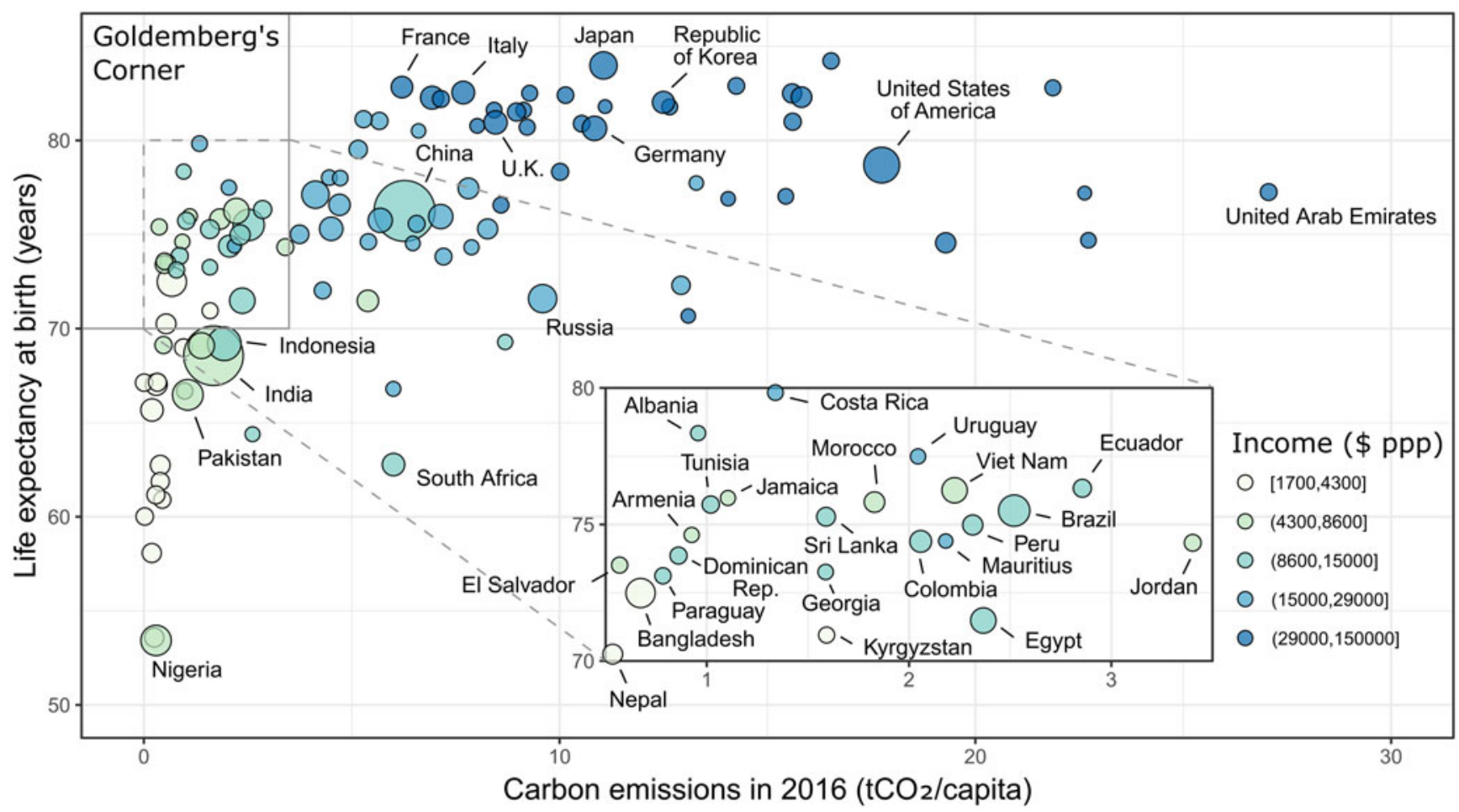

Fig. 1. Trade-adjusted $\mathrm{CO}_{2}$ emissions per capita vs. life expectancy, with Goldemberg's Corner (with high life expectancy with low carbon emissions) expanded. Dot size is proportional to population; colour shading by quintiles of income (purchasing power parity 2005 constant dollars). Updated to latest data (2016) using the same sources as Steinberger et al. (2012).

emissions associated with a 70-year life expectancy had decreased by more than a factor of 3 , and was only slightly above 2 tons of carbon dioxide per capita (Steinberger et al., 2012), bringing this life expectancy level within the reach of emerging and developing countries.

In contrast, the relation between income and emissions has not been as dynamic. On average, in 1975, an annual national income of US $\$ 10,000$ was associated with close to 8 tons of carbon dioxide per capita; and this had halved to four tons by 2005 . Emissions and income have historically been much more closely coupled when we consider the critical issue of international trade in products with high levels of 'embedded emissions' (Steinberger et al., 2012). Countries have been able to achieve much greater gains in the carbon efficiency of well-being than in the climate efficiency of economic activity (Jorgenson \& Clark, 2012). This is a crucial point, and we expect that with attention to equitable well-being, further gains are possible at low costs to the climate.

It is important to note that the results described here are for carbon emissions from fossil fuel use; taking into account the totality of greenhouse gases, including methane and nitrous oxides from agricultural processes, requires further research. Hertwich \& Peters (2009) showed that the lowest trade-adjusted non- $\mathrm{CO}_{2}$ greenhouse gases are about 1 ton of $\mathrm{CO}_{2} \mathrm{e}$ per person, even in the poorest countries, and this level may constitute a hard limit to emission reductions while maintaining sufficient agricultural production using current methods (Bajželj et al., 2014). This suggests critical future lines of research, both on lowemissions pathways and on how to drive down the floor of 'Goldemberg's Corner' for different types of economies and emissions while raising life expectancy. Similar analyses of anthropogenic environmental stressors beyond greenhouse gas emissions (to issues like desertification, biodiversity, toxins and other local pollution) are also needed.

\section{Research gaps and complexities of pathway-switching}

The diversity and dynamics of international performance in achieving well-being at various levels of carbon emissions thus suggest new research and policy directions. The research we have discussed indicates that increasing human well-being is compatible with significant decreases in carbon emissions; the challenge is to explore low-carbon development paths, appropriate or adaptable to many situations, that prioritize equitable improvements in human well-being while delivering radical emissions reductions at the level needed (IPCC, 2018; Lamb \& Rao, 2015; Meinshausen et al., 2009). It should be possible to restructure our economic systems so that human needs and quality of life are provided without undermining planetary life support systems (O’Neill et al., 2018; Pirgmaier \& Steinberger, 2019), but this will require facing the powerful forces of highly profitable industries especially those dependent upon the extraction and processing of fossil fuels (Frumhoff et al., 2015; Klein, 2014). At issue are both the ways societies develop and control technology to meet human needs, and how they manage markets, other regulation and distribution systems, and private actors to deliver these benefits at low environmental cost.

\section{Four research agendas}

The task at hand may be broken down into studying the pathways by which nations have and might in the future improve well-being 
Table 1. Some initial research questions for four groups of nations by well-being and carbon emissions. For each, we suggest three types of initial questions to guide research agendas. Type 1: Drivers and histories of development, including structural obstacles, and how to overcome them given the current political economy. Type 2: industrial, social and structural opportunities for lowering emissions, and the policy packages that would enable them. Type 3: improving well-being where needed, including strengthening public and political support for the systems that maintain well-being.

\begin{tabular}{|c|c|}
\hline Group of nations & Initial research questions \\
\hline $\begin{array}{l}\text { A: Low well-being \& low } \\
\text { emissions }\end{array}$ & $\begin{array}{l}\text { 1. What were the conditions which led to underdevelopment and low social progress (colonial history, peripheral } \\
\text { position in world trade and political systems, etc.)? } \\
\text { 2. How can 'development' be redefined to focus on well-being, without material-energy intensive economic growth? } \\
\text { How can provisioning systems be reoriented to serve the population? } \\
\text { 3. What is the energy floor above which countries need to advance to provide basic needs? And what does it depend } \\
\text { upon? How can social processes help keep this low? }\end{array}$ \\
\hline $\begin{array}{l}\text { B: Low well-being \& high } \\
\text { emissions }\end{array}$ & $\begin{array}{l}\text { 1. What are the historical drivers causing nations to fall into the trap of low well-being with high carbon emissions } \\
\text { (colonial history, extractive or heavy industry role in the world economy, local class and ethnicity divisions, etc.)? } \\
\text { 2. What mechanisms exist for exiting high resource intensity economic sectors \& industries (sunsetting, just transition, } \\
\text { divestment of specific sectors, etc.)? What types of national and international efforts would contribute? What role do } \\
\text { corruption, state and civil society capture by high carbon industries play and how can they be addressed? } \\
\text { 3. Is there an equivalent to a Green New Deal for these countries, prioritizing well-being and distributive healthy } \\
\text { economies without high resource intensity? What role can international civil society play in supporting national civil } \\
\text { society in their efforts? }\end{array}$ \\
\hline $\begin{array}{l}\text { C: High well-being \& high } \\
\text { emissions }\end{array}$ & $\begin{array}{l}\text { 1. What are the histories of the development of high-consumption societies? How do entrenched private interests } \\
\text { utilize media and political systems to prevent radical reconceptualization of consumption and decision-making? } \\
\text { 2. What elements of high-consumption societies are malleable and which are more difficult to modify (e.g. } \\
\text { electrification and renewables vs. shifting urban form to enable car-free mobility)? How can pathways to no/low } \\
\text { emissions be adapted to each country, and adopted? } \\
\text { 3. How can issues of increasing inequality and polarization be remedied, strengthening society and efforts towards } \\
\text { sustainability (deepening democratic processes; universal basic services, just transition)? }\end{array}$ \\
\hline $\begin{array}{l}\text { D: High well-being and moderate } \\
\text { emissions }\end{array}$ & $\begin{array}{l}\text { 1. What are the geographic conditions and development trajectories of nations now with relatively low emissions and } \\
\text { high well-being? How did they get there? } \\
\text { 2. What institutional, governance, cultural and social structural conditions have supported provision of high-quality } \\
\text { basic human services across social groups within nations? } \\
\text { 3. When are low emissions supported by displacing emissions outside of country borders, and what factors can } \\
\text { address such potential inequities/barriers to global sustainability? }\end{array}$ \\
\hline
\end{tabular}

while reducing emissions. Table 1 identifies some key research questions we believe are relevant for each of four groups of nations. The observed decrease in the emissions required to achieve high life expectancy is shown schematically in Figure 2 as a 'floor' of emissions which declines over time. Given the plunging costs of new renewables, it should thus be possible for countries with very low carbon emissions and low life expectancies, labelled A in the lower left hand corner of Figure 2, to raise living standards and life expectancies at fairly low carbon costs, and develop their way into Goldemberg's Corner, following the trajectory schematized. These nations now face the potential option to rapidly alter their energy systems and to avoid exploiting fossil fuels in constructing new infrastructure and provisioning systems. India's INDC from the Paris Agreement explicitly raised this choice and the need for foreign assistance and investment to avoid a great upsurge in coal consumption (UNFCCC 2015). There are emergent and off-the-shelf technologies and social arrangements that provide energy and especially energy services that enhance well-being with low climate impact, but many require substantial upfront investments.

Group B represents a smaller set of nations who have achieved neither economic prosperity nor high well-being, in spite of relatively high emissions. These nations have the most to gain in shifting to low-carbon pathways of development that prioritize human well-being, but often have the most difficult time doing so, since often their economies are dominated by natural resource extraction and the early stages of materials processing. Because there is a confluence of substantial global benefit (from greenhouse gas emissions reductions) and local benefit (from improvements in well-being and reducing local pollution), these nations should be a natural focus for international private and public cooperation. Addressing the interests of 'polluting elites', with compensation or assistance in transition to new sectors, may be most important in this group of countries (Roberts, 2001).

Group C represents countries with high well-being and high emissions (the 'developed' nations), which can still improve their overall well-being while making radical reductions in greenhouse gas emissions. Much research is ongoing on this transition, but shifting from a focus on high economic growth to prioritizing human well-being will open new opportunities for emissions reductions. There is ample evidence that increased affluence is not much coupled with well-being: beyond a rather low threshold economic growth yields sharply diminishing returns in well-being (Fanning \& O'Neill, 2019; Stone \& Krueger, 2018).

Group D consists of the diverse countries in Goldemberg's Corner, which have achieved high well-being at relatively moderate levels of emissions and energy use. These countries are not exempt from the need to decarbonize their economies, and thus their emissions can decrease modestly. However, their current achievement may help guide and inspire the countries from the three other groups in setting their pathways. Overall, research should be directed towards examining successful pathways of lowcarbon/high well-being development, assessing the requirements, conditions and benefits of following such pathways, and suggesting the technologies, policies and institutional changes that can assist countries in achieving the overarching goal of improving human well-being (Rao \& Baer, 2012). Comparative cases can be informed by 'archetype analysis' for each group of nations (Oberlack et al., 


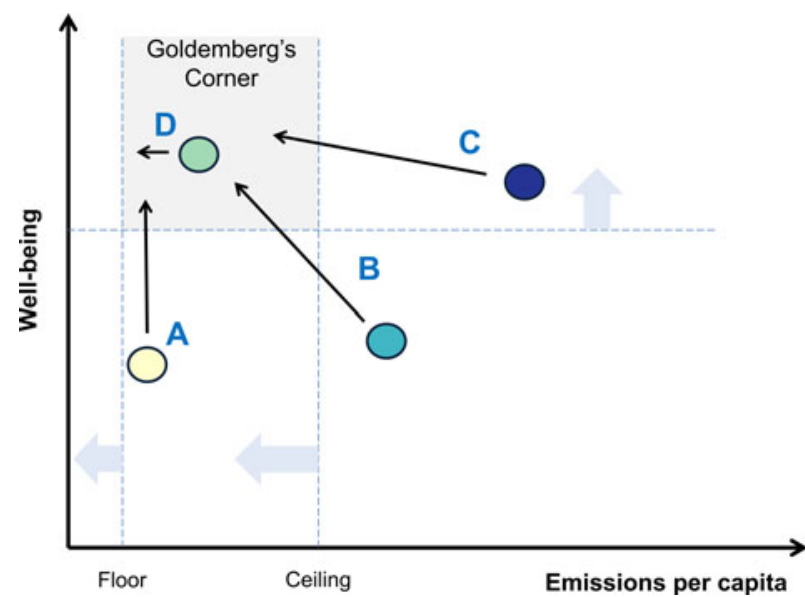

Fig. 2. Conceptual diagram of pathways required to bring four types of countries into Goldemberg's Corner (with high life expectancy with low carbon emissions). (A) Low emission (largely low-income) nations with low life-expectancy work to improve human well-being, even though this will likely increase emissions due to the greater energy consumption required to get past the floor. (B) High emitting (mostly middle income) resource extracting countries focus on improving life expectancy while sharply reducing emissions through pathway switching to lower carbon and more diversified economies. (C) (Mostly wealthy) high emitters sharply improve energy efficiency of well-being and decarbonize, while restraining excessive consumption through market or regulatory means. (D) Countries already achieving high well-being at low emissions stabilize, and ultimately decarbonize to net-zero emissions. Fain arrows on emissions per capita floor and ceiling of Goldemberg's Corner indicate changing technology and national focus on well-being could lead those to decline. Vertical arrow on rising well-being from a high baseline indicates rising technical capabilities and social expectations for 'well-being'.

2019). Research needs to include the difficult political, judicial, cultural and institutional changes required to support these transitions (e.g. Newell 2018; Newell \& Mulvaney 2013; Scoones et al., 2015). Again, much of this work will be nation-specific, informed by national political, economic and social structures.

\section{Future steps}

The research effort proposed here requires new kinds of modelling: combining decarbonization of energy and other production processes with sustainable energy access and goals (Pachauri, 2014). Within affluent nations, special consideration for regions and groups adversely affected by emissions reduction policies may also be warranted, for example as proposed in the USA Green New Deal resolution (Ocasio-Cortez, 2019). Understanding the social and political barriers to switching from high-carbon to lower-carbon modes of production and consumption, and ways to overcome them, will be fundamental. Existing technology now makes it feasible to achieve low carbon emissions and high human well-being for all nations (Grubler et al., 2018). But the barriers are substantial, and include active lobbying against regulation by vested interests (InfluenceMap 2019; Moe 2015), technological and social lock-in (Ivanova et al., 2018), and, despite growing awareness, a fragile public discourse on appropriate responses to climate change (Drews \& van den Bergh, 2016; Fairbrother, 2017). Such barriers are differentiated by country and world region, and even within nations. Research has mapped out organized networks of climate denial in the USA (Farrell et al., 2019). The international spread of this counter-movement remains underexplored; as are the links between institutional capabilities, corruption and climate policy failure in developing and middle-income countries (Lockwood, 2015). Unfortunately, these areas are currently the weakest link in the existing research and policy chain (Pirgmaier \& Steinberger, 2019).

The Intended Nationally-Determined Contributions (INDCs) submitted in the 2015 Paris round of negotiations must be connected to national development planning, beginning the difficult steps to switch from high-carbon pathways to lower carbon ones. Eventually, scientific evidence of planetary boundaries and emissions pathways needs to be the basis of adequate national and global emission limits. 'Just transitions' for high-carbon industry workers, communities and nations, incentives for sector and technology switching, compensation for some stranded assets, and dematerialization strategies will all be important elements of pathway switching (Wilson et al., 2012). Harnessing productivity growth to reduce working hours rather than merely expanding output is a potent approach to reducing emissions (Fitzgerald et al., 2018; Knight et al., 2013). And policies for moving resource-rich middle-income countries to lower emissions with higher human well-being remain underexplored.

There is much to be done in both research and policy experimentation (Table 1), and given the sharp reductions in global emissions needed to remain below 1.5 or even $2{ }^{\circ} \mathrm{C}$ warming, the time is short (IPCC, 2018). Shifting away from a singular focus on increased gross domestic product per capita towards advancing human well-being with low stress on the environment would focus attention on forms of development that provide human benefits. This revised framing may open paths to a future that is more sustainable, healthier and more equitable (Jorgenson et al., 2017, 2018).

Acknowledgements. This analysis was initiated during discussions at the 20th Meeting of the Society for Human Ecology, Bar Harbor, Maine, USA. William Clark and several anonymous reviewers have provided useful feedback on an earlier version.

Author contributions. All authors participated in a workshop at the Meeting of the Society for Human Ecology where the article was conceived. JS proposed the conceptual framework, JR led drafting and revisions, and all contributed to writing and editing. WL and JS conducted data gathering, WL produced the figures.

Financial support. This research received no specific grant from any funding agency, commercial or not-for-profit sectors.

Conflicts of interest. None.

\section{Notes}

i An anonymous reviewer suggested this list, which we believe is a very good start: '(1) countries where other factors have historically produced well-being anyway; (2) uses of energy that are not fossil-fuel related or don't produce many emissions; (3) how distribution of access to energy and resources relates to well-being; (4) variations within countries of life expectancy levels; (5) the literature which emphasizes inter-personal relationships and companionship as important determinants of well-being; (6) the fact that resource consumption does not have a fixed relation to emissions; and (7) the role of trade adjusted emissions'.

ii Agronomist and former Environment Minister of Brazil Jose Goldemberg led a 1985 study in Ambio titled 'Basic needs and much more with 1 kilowatt per capita' (Goldemberg et al., 1985). This introduced the idea that there is the possibility of well-being with very low energy use; we apply that idea to carbon emissions.

\section{References}

Atteridge, A., Verkuijl, C., \& Dzebo, A. (2019). Nationally determined contributions (NDCs) as instruments for promoting national development 
agendas? An analysis of small island developing states (SIDS). Climate Policy. Retrieved from https://dx.doi.org/10.1080/14693062.2019.1605331.

Bajželj, B., Richards, K. S., Allwood, J. M., Smith, P., Dennis, J. S., Curmi, E., \& Gilligan, C. A. (2014). Importance of food-demand management for climate mitigation. Nature Climate Change, 4(10), 924.

Brulle, R. J. (2019). Networks of opposition: a structural analysis of US climate change countermovement coalitions 1989-2015. Sociological Inquiry. Retrieved from https://doi.org/10.1111/soin.12333.

Dietz, T., Rosa, E. A., \& York, R. (2009). Environmentally efficient well-being: rethinking sustainability as the relationship between human well-being and environmental impacts. Human Ecology Review, 16, 114-123.

Dietz, T., Rosa, E. A., \& York, R. (2012). Environmentally efficient well-being: is there a Kuznets curve? Applied Geography, 32(1), 21-28.

Drews, S. \& van den Bergh, J. C. J. M. (2016). What explains public support for climate policies? A review of empirical and experimental studies. Climate Policy, 16, 855-876.

Fairbrother, M. (2017). Environmental attitudes and the politics of distrust. Sociology Compass, 11(5), 1-10.

Fanning, A. L. \& O'Neill, D. W. (2019). The Wellbeing-Consumption paradox: happiness, health, income, and carbon emissions in growing versus nongrowing economies. Journal of Cleaner Production, 212, 810-821.

Farrell, J., McConnell, K., \& Brulle, R. (2019). Evidence-based strategies to combat scientific misinformation. Nature Climate Change, 9, 191-195.

Fitzgerald, J. B., Schor, J. B., \& Jorgenson, A. K. (2018). Working hours and carbon dioxide emissions in the United States, 2007-2013. Social Forces, 96(4), 1851-1874.

Frumhoff, P. C., Heede, R., \& Oreskes, N. (2015). The climate responsibilities of industrial carbon producers. Climatic Change, 132(2), 157-171.

Geronimus, A. T., Bound, J., Waidmann, T. A., Colen, C. G., \& Steffick, D. (2001). Inequality in life expectancy, functional status, and active life expectancy across selected black and white populations in the United States. Demography, 38(2), 227-251.

Givens, J. E. (2017). World society, world polity, and the carbon intensity of well-being, 1990-2011. Sociology of Development, 3(4), 403-435.

Givens, J. E. (2018). Ecologically unequal exchange and the carbon intensity of well-being, 1990-2011. Environmental Sociology, 4(3), 311-324.

Goldemberg, J., Johansson, T. B., Reddy, A. K., \& Williams, R. H. (1985). Basic needs and much more with one kilowatt per capita. Ambio, 14, 190-200.

Gough, I. (2015). Climate change and sustainable welfare: the centrality of human needs. Cambridge Journal of Economics, 39(5), 1191-1214.

Grubler, A., Wilson, C., Bento, N., Boza-Kiss, B., Krey, V., McCollum, D. L., Rao, N. D., Riahi, K., Rogelj, J., De Stercke, S., \& Cullen, J. (2018). A low energy demand scenario for meeting the $1.5 \mathrm{C}$ target and sustainable development goals without negative emission technologies. Nature Energy, 3(6), 515.

Hertwich, E. G. \& Peters, G. P. (2009). Carbon footprint of nations: a global, trade-linked analysis. Environmental Science \& Technology, 43(16), 64146420.

InfluenceMap (2019). Big Oil's Real Agenda on Climate Change. London. Retrieved from https://influencemap.org/report/How-Big-Oil-Continuesto-Oppose-the-Paris-Agreement-38212275958aa21196dae3b76220bddc.

IPCC (2018). Global Warming of $1.5^{\circ} \mathrm{C}$. An IPCC Special Report on the Impacts of Global Warming of $1.5^{\circ} \mathrm{C}$ Above Pre-industrial Levels and Related Global Greenhouse Gas Emission Pathways, in the Context of Strengthening the Global Response to the Threat of Climate Change, Sustainable Development, and Efforts to Eradicate Poverty [V. Masson-Delmotte, P. Zhai, H.-O. Pörtner, D. Roberts, J. Skea, P.R. Shukla, A. Pirani, W. Moufouma-Okia, C. Péan, R. Pidcock, S. Connors, J.B.R. Matthews, Y. Chen, X. Zhou, M.I. Gomis, E. Lonnoy, T. Maycock, M. Tignor, \& T. Waterfi (eds)]. Retrieved from https://www.ipcc.ch/sr15/.

Ivanova, D., Vita, G., Wood, R., Lausselet, C., Dumitru, A., Krause, K., Macsinga, I., \& Hertwich, E.G. (2018). Carbon mitigation in domains of high consumer lock-in. Global Environmental Change, 52, 117-130.

Jorgenson, A. K. (2014). Economic development and the carbon intensity of human well-being. Nature Climate Change, 4(3), 186-189.

Jorgenson, A. K. \& Clark, B. (2012). Are the economy and the environment decoupling? A comparative international study, 1960-2005. American Journal of Sociology, 118(1), 1-44.
Jorgenson, A., Schor, J., \& Huang, X. (2017). Income inequality and carbon emissions in the United States: a state-level analysis, 1997-2012. Ecological Economics, 134, 40-48.

Jorgenson, A. K., Dietz, T., \& Kelly, O. (2018). Inequality, poverty, and the carbon intensity of human well-being in the United States: a sex-specific analysis. Sustainability Science, 13(4), 1167-1174.

Klein, N. (2014). This Changes Everything: Capitalism vs. the Climate. Simon and Schuster.

Knight, K. W. \& Rosa, E. A. (2011). The environmental efficiency of wellbeing: a cross-national analysis. Social Science Research, 40(3), 931-949.

Knight, K. W., Rosa, E. A., \& Schor, J. B. (2013). Could working less reduce pressures on the environment? A cross-national panel analysis of OECD countries, 1970-2007. Global Environmental Change, 23(4), 691-700.

Lamb, W. F. \& Rao, N. D. (2015). Human development in a climateconstrained world: what the past says about the future. Global Environmental Change, 33, 14-22.

Lamb, W. F. \& Steinberger, J. K. (2017). Human well-being and climate change mitigation. Wiley Interdisciplinary Reviews: Climate Change, 8(6), e485.

Lamb, W. F., Steinberger, J. K., Bows-Larkin, A., Peters, G. P., Roberts, J. T., \& Wood, F. R. (2014). Transitions in pathways of human development and carbon emissions. Environmental Research Letters, 9(1), 014011.

Lockwood, M. (2015). Fossil fuel subsidy reform, rent management and political fragmentation in developing countries. New Political Economy, 20(4), 475-494.

Mazur, A. \& Rosa, E. (1974). Energy and life-style: massive energy consumption may not be necessary to maintain current living standards in America. Science, 186(4164), 607-610.

McCollum, D. L., Zhou, W., Bertram, C., De Boer, H-S., Bosetti, V., Busch, S., ... \& Riahi, K. (2018). Energy investment needs for fulfilling the Paris Agreement and achieving the Sustainable Development Goals. Nature Energy, 3(7), 589.

Meinshausen, M., Meinshausen, N., Hare, W., Raper, S. C., Frieler, K., Knutti, R., ... \& Allen, M. R. (2009). Greenhouse-gas emission targets for limiting global warming to 2 C. Nature, 458(7242), 1158.

Moe, E. (2015). Renewable Energy Transformation or Fossil Fuel Backlash Vested Interests in the Political Economy. Palgrave Macmillan.

Newell, P. (2018). Trasformismo or transformation? The global political economy of energy transitions. Review of International Political Economy, 26(1), 25-48.

Newell, P. \& Mulvaney, D. (2013). The political economy of the just transition'. The Geographical Journal, 179(2), 132-140.

Oberlack, C., Sietz, D., Bürgi, E., Brémond, A. C., Dell'Angelo, J., Eisenack, K., ... \& Kimmich, C. (2019). Archetype analysis in sustainability research: meanings, motivations, and evidence-based policy making. Ecology and Society, 24(2). Retrieved from https://doi.org/10.5751/ES-10747-240226.

Ocasio-Cortez, Rep. A. (2019). H.Res.109 - Recognizing the duty of the Federal Government to create a Green New Deal. U.S. Congress. Introduced 7 Feb 2019.

OECD (2013). OECD Guidelines on Measuring Subjective Well-being. Retrieved from https://www.oecd.org/statistics/oecd-guidelines-on-measuring-subjective-well-being-9789264191655-en.htm.

O'Neill, D. W., Fanning, A. L., Lamb, W. F., \& Steinberger, J. K. (2018). A good life for all within planetary boundaries. Nature Sustainability, 1(2), 88.

Otto, I.M., Kim, K.M., Dubrovsky, N., \& Lucht, W. (2019). Shift the focus from the super-poor to the super-rich. Nature Climate Change, 9(2), 82.

Pachauri, S. (2014). Household electricity access a trivial contributor to $\mathrm{CO}_{2}$ emissions growth in India. Nature Climate Change, 4(12), 1073.

Pirgmaier, E. \& Steinberger, J. K. (2019). Roots, riots, and radical change - a road less travelled for ecological economics. Sustainability, 11(7), 2001.

Rao, N. D. \& Baer, P. (2012). "Decent living" emissions: a conceptual framework. Sustainability, 4(4), 656-681.

Rao, N. D. \& Min, J. (2017). Decent living standards: material prerequisites for human wellbeing. Social Indicators Research, 1-20. Retrieved from https:// doi.org/10.1007/s11205-017-1650-0.

Roberts, J. T. (2001). Global inequality and climate change. Society \& Natural Resources, 14(6), 501-509.

Rogelj, J., Den Elzen, M., Höhne, N., Fransen, T., Fekete, H., Winkler, H., Schaeffer, R., Sha, F., Riahi, K., \& Meinshausen, M. (2016). Paris Agreement climate proposals need a boost to keep warming well below $2^{\circ} \mathrm{C}$. Nature, 534(7609), 631-639. 
Scoones, I., Leach, M., \& Newell, P. (eds) (2015). The Politics of Green Transformations. Routledge.

Sheehan, K. (2018). This ain't your daddy's greenwashing: an assessment of the American Petroleum Institute's Power Past Impossible campaign. In M. Rimmer (ed.), Intellectual Property and Clean Energy. Retrieved from https://doi.org/10.10007/978-981-13-2155-9_11.

Smil, V. (2008). Energy in Nature and Society: General Energetics of Complex Systems. MIT Press.

Steinberger, J. K. \& Roberts, J. T. (2010). From constraint to sufficiency: the decoupling of energy and carbon from human needs, 1975-2005. Ecological Economics, 70(2), 425-433.

Steinberger, J. K., Roberts, J. T., Peters, G. P., \& Baiocchi, G. (2012). Pathways of human development and carbon emissions embodied in trade. Nature Climate Change, 2(2), 81.

Stiglitz, J. E., Sen, A., \& Fitoussi, J. P. (2010). Mismeasuring our Lives: Why GDP Doesn't Add Up. The New Press.
Stiglitz, J. E., Sen, A., \& Fitoussi, J. P. (2017). Report by the Commission on the Measurement of Economic Performance and Social Progress. Commission on the Measurement of Economic Performance and Social Progress.

Stone, A. A. \& Krueger, A. B. (2018). Understanding subjective well-being. In J. E. Stiglitz, J.-P. Fitoussi, \& M. Durand (eds), For Good Measure: Advancing Research on Well-being Metrics Beyond GDP (pp. 163-201). OECD Publishing.

UNEP (2018). Emissions Gap Report 2018. UNEP. Retrieved from https://www. unenvironment.org/resources/emissions-gap-report-2018.

UNFCCC (2015). Intended Nationally-Determined Contributions (INDCs) as Communicated by Parties. UNFCCC. https://www4.unfccc.int/sites/submissions/INDC/Submission\%20Pages/submissions.aspx; Updates at: http:// unfccc.int/focus/indc_portal/items/8766.php.

Wilson, C., Grubler, A., Gallagher, K. S., \& Nemet, G. F. (2012). Marginalization of end-use technologies in energy innovation for climate protection. Nature Climate Change, 2(11), 780. 